\title{
Flora of Paraíba, Brazil: Bombacoideae Burnett (Malvaceae)
}

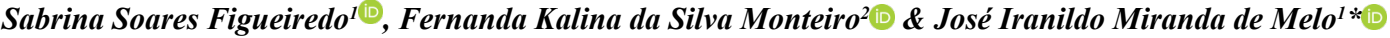 \\ ${ }^{1}$ Universidade Estadual da Paraíba, Programa de Pós-Graduação em Ecologia e Conservação, Departamento \\ de Biologia, CEP: 58429-500, Campina Grande, PB, Brasil. \\ ${ }^{2}$ Universidade Federal Rural de Pernambuco, Programa de Pós-Graduação em Botânica, Departamento de \\ Biologia, CEP: 52171-900, Recife, PE, Brasil \\ * Corresponding author: José Iranildo Miranda de Melo, e-mail: tournefort@gmail.com
}

FIGUEIREDO, S.S., MONTEIRO, F.K.S., MELO, J.I.M. Flora of Paraíba, Brazil: Bombacoideae Burnett (Malvaceae). Biota Neotropica 20(2): e20190837. https://doi.org/10.1590/1676-0611-BN-2019-0837.

\begin{abstract}
This work presents the taxonomic study of the native species of Bombacoideae Burnett (Malvaceae) in the state of Paraíba, Northeastern Brazil. The taxonomic treatment included keys for identifying genera and species, morphological descriptions, diagnostic illustrations, comments on taxonomic affinities, and additional information on geographical distribution, habitat, and flowering and fruiting of the species. Three genera and six species were recorded: Ceiba Mill., represented by C. glaziovii (Kuntze) K. Schum., is a new record for the Atlantic Forest; Eriotheca Schott \& Endl., represented by E. gracilipes (K. Schum.) A. Robyns and E. macrophylla (K. Schum.) A. Robyns, is a new record for Paraíba; and Pseudobombax Dugand, which is represented by P. marginatum (A.St.Hil., Juss. \& Cambess.) A. Robyns, P. parvifolium Carv.-Sobr. \& L.P. Queiroz and P. simplicifolium A. Robyns Robyns - the last one registered for the first time in Paraíba in this study.

Keywords: conservation; diversity; endemism; Northeastern, Brazil; taxonomy.
\end{abstract}

\section{Flora da Paraíba, Brasil: Bombacoideae Burnett (Malvaceae)}

Resumo: Este trabalho apresenta o estudo taxonômico das espécies de Bombacoideae Burnett (Malvaceae) nativas para a Paraíba, nordeste brasileiro. O tratamento taxonômico incluiu chaves para identificação de gêneros e espécies, além de descrições morfológicas, ilustrações dos caracteres diagnósticos, comentários sobre afinidades taxonômicas, dados de distribuição geográfica, habitats, floração e frutificação das espécies. Foram registrados três gêneros e seis espécies: Ceiba Mill., está representado por C. glaziovii (Kuntze) K. Schum. e constitui um novo registro para a Mata Atlântica; Eriotheca Schott \& Endl. consiste em um novo registro para a Paraíba, representado por duas espécies: E. gracilipes (K. Schum.) A. Robyns e E. macrophylla (K. Schum.) A. Robyns; e Pseudobombax Dugand, com três espécies: P. marginatum (A.St.-Hil., Juss. \& Cambess.) A. Robyns, P. parvifolium Carv.-Sobr. \& L.P. Queiroz e P. simplicifolium A. Robyns, essa última sendo registrada pela primeira vez para o Estado nesse estudo. Palavras-chave: conservação; diversidade; endemismo; Nordeste, brasileiro; taxonomia. 


\section{Introduction}

Malvaceae Juss. includes about 250 genera and 4,200 species, showing predominantly a pantropical distribution (Judd et al. 2009). Morphologically, this family is primarily characterized by presenting a nectariferous tissue located at the base of the calyx (or, less often, of the petals or sepals), valvular androgynophore, mucilage channels, and leaves with primary palminervate venation (Judd \& Manchester 1997, Judd et al. 1999).

Bombacaceae, formally known as Bombacoideae in phylogenetic classification systems, is now inserted in Malvaceae sensu lato (s.1.) as one of its nine monophyletic subfamilies, corroborated the studies of Baum et al. (1998), APG I (1998), Alverson et al. (1999) and APG IV (2016).

Bombacoideae gathers approximately 18 genera and 187 species, most of them pantropical with a greater diversity of species in the rainforests of South America. Brazil and Colombia are the more prominent countries for their highest representativeness in relation to the number of species (Gibbs \& Semir 2003). According to the BFG (2015), 13 genera and about 80 species can be found in Brazil, mainly in the North and Northeast regions of the country.

Their species of Bombacoideae usually present deciduous leaves, with sessile or petiolate leaflets; often large flowers with sepals generally concrescent and glandular trichomes at the base; the receptacle is usually glandular; the ovary is superolateral, and the fruits, to the vast majority of their representatives, are capsule opening for 3-5 valves, with plentiful silky fibers and generally oilseeds inside (Reyes 1998, Bocage-Neta \& Sales 2002, Aguiar 2012).

In general, the representatives of Bombacoideae have great economic importance and the can be used for various purposes: the wood can be used for manufacturing small boats, furniture, light objects, and cellulose paste; the wool that surrounds the seeds can be used for making life jackets, filling mattresses, pillows and as a thermal insulator; some seeds can be edible; in the ornamentation of squares (Esteves 2005, Lorenzi 2002a, Lorenzi 2002b). Their representatives can also used in the reforestation of degraded areas as they are considered to be rapidly growing (Lorenzi 2002a, Lorenzi 2002b).

Considering the representativeness of Bombacoideae in Brazil and the scarcity of studies in the Northeast region (e.g., Gibbs \& Semir 2003, Esteves 2005, Carvalho-Sobrinho \& Queiroz 2008, Carvalho-Sobrinho \& Queiroz 2010, Duarte 2010, Duarte et al. 2011, Carvalho-Sobrinho 2013), the objective of this work was to elaborate taxonomic study of this subfamily in the state of Paraíba in order to enlarge the knowledge on its richness and geographical distribution. Identification keys genera and species, morphological descriptions and illustrations, data on geographic distribution and preferred environments, in addition to the phenology of the species found in the study area are presented.

\section{Material and Methods}

\section{Study area}

The State of Paraíba (Figure 1) is located in the Northeast of Brazil and includes 223 municipalities. It presents a territorial extension of $56,469.744 \mathrm{~km}^{2}$ divided into four meso-regions: Zona da Mata, Agreste, Borborema and hinterland (IBGE 2018). Its vegetation consists of mangroves (on the coast), a small strip of rainforest (Mata Atlântica) that stretches along the coast and enters to the West, forming projections associated with humid areas (elevated wetlands, Caatinga) and, in most parts, the Caatinga that comprises about $80 \%$ of the territory in which the vegetation vary between closed bushy-arboreal to closed arboreal caatinga (Figure 2) (Paraíba 2018, Portal Brasil 2018).
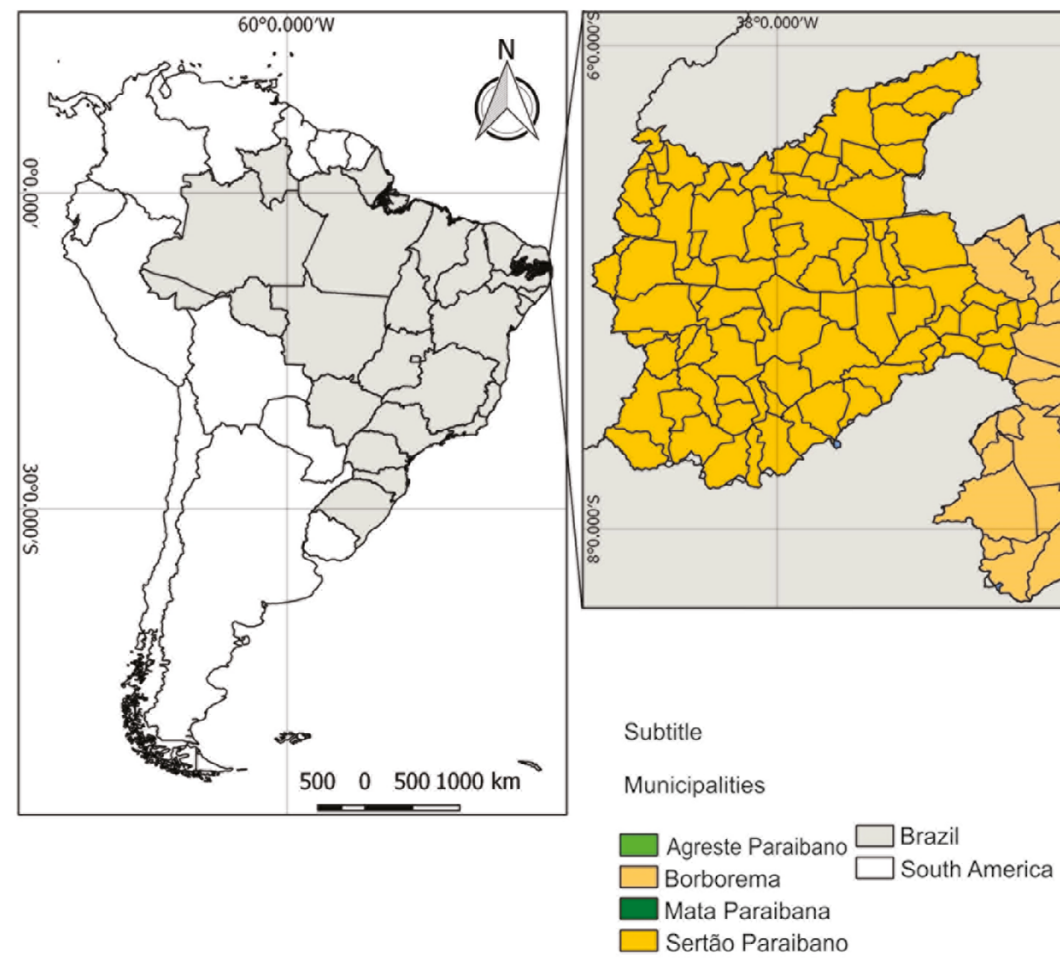

Data Base: IBGE, 2016

Geographical Coordinate System Datum: SIRGAS 2000.

Figure 1. Location of the study area, State of Paraíba, Northeastern Brazil (Map: Rodrigues, E.M. 2017). 

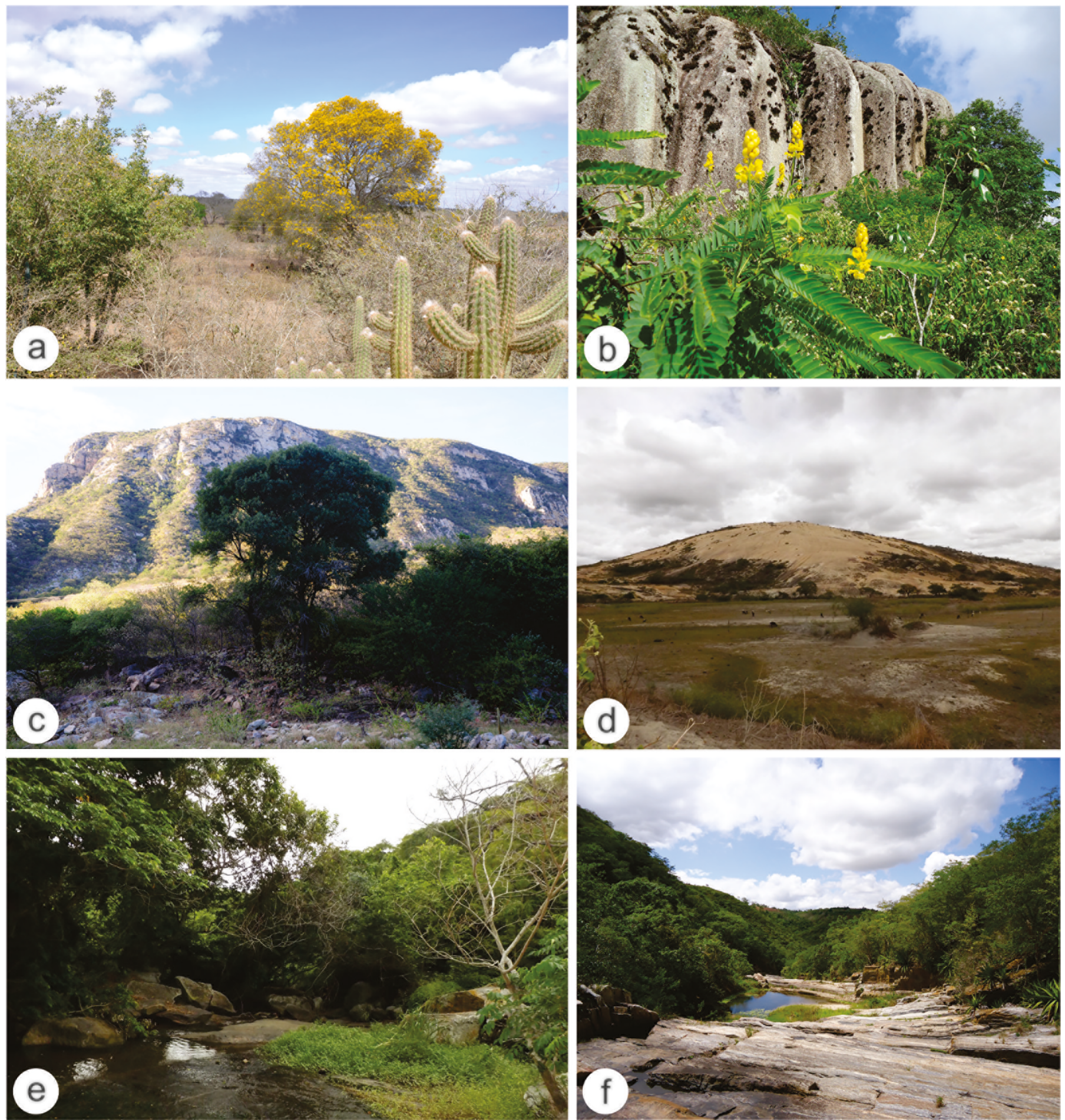

Figure 2. Preferred environments of the Bombacoideae species (Malvaceae) found in the State of Paraíba: a. APA do Cariri, Boa Vista; b. Outcrop in Puxinanã; c. Serra of the ABA, Passagem; d. Serra Branca; e. Roncador Falls, Bananeiras; f. Do Pinga Waterfalls, Lagoa Seca (Photos: A-C. Costa, S.L.; B. H. Crisóstomo; D-E. Monteiro, F.K.S.; F. Sousa, T.S.).

\section{Collecting expeditions and preservation}

Monthly expeditions from August/2016 to February/2018 were made to several municipalities of Paraíba, covering areas of the Caatinga and the Atlantic Rainforest vegetation. Vegetative samples (stems and leaves) and fertile specimens (with flowers and/or fruit) of Bombacoideae representatives were collected. These samples were herborized and/or fixed in alcohol (70\%) for detailed posterior morphological analyses, according to Peixoto \& Maia (2013). These analyses were made in the laboratory of Botany and the specimens were incorporated into the collection of the Herbarium Manuel de 
Figueiredo, S. S. et al.

Arruda Câmara (HACAM), both of the Department of Biology, Campus I, of the State University of Paraíba (UEPB).

\section{Taxonomic study}

Morpho-taxonomic analyses were carried out between September/2016 and February/2018. During this stage, vegetative and reproductive structures were examined and resulted in the indentification of genera and species.

The identifications were based on the bibliography of Bombacaceae, Bombacoideae and Malvaceae s.l. specially the studies of: Reyes (1998), Bocage-Neta \& Sales (2002), Gibbs \& Semir (2003), CarvalhoSobrinho \& Queiroz (2008), Esteves (2005), Carvalho-Sobrinho \& Queiroz (2010) and Carvalho-Sobrinho (2013). In addition, classical literature about the group was also consulted: De Candolle (1824); Bentham \& Höoker (1862) and Schumann (1886). The collections available on SpeciesLink, Tropics (www.tropicos.org) and Virtual Herbarium of Flora and fungos (Reflora) were also examined.

For morphological descriptions, specimens (vouchers) from the herbaria of Paraíba (CSTR, EAN, HACAM and JPB), Pernambuco (IPA and PEUFR) and Rio de Janeiro (RB), complemented by its own collections were used. Due to the lack of diagnostic structures such as flowers and fruits, the descriptions of some taxa were also based on additional specimens. The diagnosis of Eriotheca gracilipes, E. macrophylla and Pseudobombax simplicifolium were complemented by plant specimens from the online collections of herbaria online CEPEC, JPB and RB. Approximately 800 samples were analyzed from both physical holdings and scanning-based materials (Reflora). The herbaria acronyms follow Thiers et al. (continuously updated).

The following specific terminologies were adopted: foliar typification (Rizzini 1977), venation patterns (Hickey 1973), indument (Payne 1978). In general, for the description of vegetative and reproductive structures, Hickey \& King (2000) was followed.

An identification key and illustrations of the main diagnostic charactres were prepared. The taxonomic treatment includes morphological descriptions, illustrations in Nankin ink and images of species and environments, the period of flowering and fruiting (phenology), geographic distribution, preferred environments and taxonomic, and taxonomic comments.

\section{Results and Discussion}

\section{Taxonomic Treatment}

\section{Bombacoideae Burnett}

Bombacoideae is characterized by the leaves usually deciduous, petiolate, alternate, simple or composed, scanned with sessile or petiolate, articulate or inarticulate leaflets (Bocage-Neta \& Sales 2002). The flowers are often bracteolate, large, hermaphroditic, actinomorphous, rarely more or less zigomorphous, usually pentamerous; sepals free or concrescent with glandular trichomes on the base; the receptacle generally glandular. Calyx usually campanulate; petals 5 , usually adnate to the base of the stem tube; 5 -numerous stamens usually monadelphous or poliadelphous, epipetalous; 1-thecae to numerous thecae, pistil 2-5 (10) -carpels, sincarpic, upper ovary, sometimes semi-infero, 2-10, $1-2$ or locules with many ovule, capitate stigma. The fruit is usually the capsule type, smooth, sometimes prickly, fleshy, usually winged, opening for 3-5 valves, with plentiful silky fibers in its interior. The seeds are usually oilseeds (Reyes 1998, Aguiar 2012).

In the study area, the subfamily is represented by three genera and six species. One genus (Eriotheca) and three species (E. gracilipes, E. macrophylla and Pseudobombax simplicifolium) represent new records for Paraíba.

Ceiba glaziovii had already been registered in areas of the Caatinga of the state of Paraíba, but, through this research, its istribution is now extended to areas of the Atlantic Forest.

Pseudobombax Dugand was the most representative genus, with three species [P. marginatum (A. St.-Hil., Juss. \& Cambess.) A. Robyns, P. parvifolium Carv.-Sobr. \& L.P. Queiroz and P. simplicifolium A. Robyns] all of them associated with the phytophysiognomy of Caatinga, followed by Eriotheca Schott \& Endl., with two species (E. gracilipes and E. macrophylla), both associated with the Atlantic Forest (elevated wetlands), and Ceiba Mill., with the species C. glaziovii (Kuntze) K. Schum., associated with both the Caatinga and Atlantic Forest areas (elevated wetlands).

Key to the identification of species of Bombacoideae recorded in Paraíba, Brazil

1. Stem aculeate with protuberance in the middle; stamens $5 \ldots \ldots \ldots . . .$. 1.1. Ceiba glaziovii

1. Stem unarmed; ; stamens more than 5 2

2. Lepidote leaflets; stamens constricted at the median portion until the base of the staminal tube 3

3. Coriaceous leaflets; obovoid flower buds, calyx lepidote -brown externally 2.1. Eriotheca gracilipes

3. Carthaceous leaflets; oblong flower buds, calyx floccose ferrugineous externall 2.2. Eriotheca macrophylla

2. Glabrescent to pubescent leaflets; stamens constricted only at the of the staminal tube.

4

4. 3-leaflets leaves, united at the apex in braquiblasts (short stems) 3.3. Pseudobombax simplicifolium

4. 5-7 leaflets leaves, whitout braquiblasts (short stems)..................5

5. Stem rectilinear with dark green longitudinal streaks; seeds reniform 3.2. Pseudobombax parvifolium

5. Irregular stem with greenish amorphous excrescences; seeds piriform 3.1. Pseudobombax marginatum 
The genus includes 22 species, most of them restricted to seasonally dry forests of Brazil (Gibbs \& Semir 2003). In the Brazilian territory, Ceiba occurs from Mato Grosso do Sul to the northern Caatingas of the states of Minas Gerais and Bahia (Flora do Brasil 2020 in preparation), almost always associated with rocky outcrops, rock fields, and limestone fields.

Morphologically, Ceiba can be characterized by presenting: robust and aculeate stems, with aculeous that propagating all over the branches, without longitudinal streaks, large canopy, leaves alternate, compounddigitate with long petioles, leaflets 5-7, with serrate margins; flowers solitary or in few-flowered inflorescences, pentamerous, diclamydeous, the outside surface of the petals covered with simple trichomes, stamens 5 , anthers bithecae, stem tube with or without appendages. Capsule 5-valvate, with abundant wool, seeds numerous, subglobose, without streaks; hilum protruding (Gibbs \& Semir 2003). In the study area, Ceiba is represented by the species $C$. glaziovii, recorded in Caatinga vegetation (Agreste and Borborema).

1.1. Ceiba glaziovii (Kuntze) K. Schum., Bot. Jahresber. (Just) 26 (1): 343. 1900.

Trees, 14-15 m high; large canopy. Aculeate stem, including the young branches, with protuberance in the middle. Stipules absent. Compound leaves, digitate, 5-7 foliolated; petiole $80 \mathrm{~mm}$ long, $12.5 \times 5 \mathrm{~cm}$ leaflets, oblanceolate, elliptical, membranaceous, acuminate apex, base cuneate to attenuated, entire margin from basis until the median region, serrate from median region until the apex, main vein salient on both sides propagating until the apex, glabrescent, secondary veins evident on both sides propagating until the apex, glabrescent, craspedodromous venation; solitary flowers, axillary, $8 \mathrm{~cm}$ long, scales absent, oblong and imbricate buds; pedicel $26 \mathrm{~mm}$ long; calyx $2.5 \times 1.8 \mathrm{~cm}$, campanulate, lobes 5 , lightly apiculate, externally glabrous and internally with simple trichomes, nectariferous glands at the base of the receptacle; corolla 5.2 $\times 2.2 \mathrm{~cm}$, spatulate, obovate apex, white, lilac to pink macules on the inner surface and simple trichomes in lower density; white exterior face, covered with simple trichomes, staminal tube $5 \mathrm{~cm}$ long, constricted to the median portion; stamens 5 , distally free among each other, longitudinal fillaments $4.3 \mathrm{~cm}$ long, anthers $0.6-0.7 \mathrm{~cm}$ long, rimose, bitheca, glabrous, stigma 5-lobed; super ovary, with oil glands between the locules. Capsule 11-15 × $7 \mathrm{~cm}$, oblong, 5-valvate, glabrous, valves 0.9-1.0 diam, epicarp porous, abundant wool. Seeds $0.7-0.6 \mathrm{~mm}$ long, reniforms.

Specimens examined: BRAZIL. PARAIIBA: Areia, Mata do Pau Ferro, 7¹8'.07'S and 36²' '24'W, 05.X.1999, fl., M.R. Barbosa 1843 (JPB); CCA, 6 ${ }^{\circ} 58^{\prime} .34^{\prime \prime}$ S and 35\%41'.56"W 11.IX.2013, fl., L.P. Felipe 14.367 (EAN); Aroeiras, 7³5'.05”S and 35\%42'.56”W, 27.IX.1994, fl., M.F. Agra et al. 3297 (JPB); Boa Vista, APA do Cariri, 7¹8'.07'S and $36^{\circ} 42^{\prime} .24$ 'W, 28.VII.2016, fl., S.S. Figueiredo 22 (HACAM); 26.X.2016, fr., S.S. Figueiredo 35 (HACAM); Ibidem, São Joãozinho, $07^{\circ} 17^{\prime} 015^{\prime}$ 'S and $036^{\circ} 16^{\prime} 567^{\prime \prime W}, 17 . V I I I .2016$, fl., S.S. Figueiredo 25 (HACAM); Cabaceiras, Lajedo de Pai Mateus, $7^{\circ} 27^{\prime} .10^{\prime \prime}$ S and 36¹9'.00”'W, 22.IX.2007, fl., B.I. Lima; R.J. Lima; C.E.L. Lourenço; C.M. Pessoa \& G.A. Costa 43 (JPB); Cajá, 7¹2'.27'S and 35²0'.17'W, 14.X.1979, fl., M.F. Agra 180 (JPB); Campina Grande, 7¹4'.34”S and 35'54'.05"W, 21.IV.1953, fl., L. Xavier s.n. (JPB 1714); Desterro, $7^{\circ} 18^{\prime} .31^{\prime \prime S}$ and $37^{\circ} 05^{\prime} .40^{\prime \prime W}, 10 . X I I .1993$, Fl., M.F. Agra; E.A.
Rocha; E. Locatelli; S. Formiga 2284 (JPB); Dona Inês, Mata do Seró, 6 36'.38"'S and 35'38'.44"'W 09.IV.2008, fl., K.R.F. Xavier 43 (EAN); Esperança, 701'.17'’S and 35051'.27''W, 07.XII.2015, fl., S.S. Figueiredo 09 (HACAM); Juarez Távora, 701'.24”S and 3549'.16”W, 05.IX.1996, M.R. Barbosa 1530 (JPB); Lagoa Seca, Faz. Ipuarana, $7^{\circ} 08^{\prime} .52$ 'S and 35'51'.30'W, 25.IX.2001, fl., A. Serafim; G. Clara; E. Lourenço (JPB 28.660); Maturéia, Pico do Jabre, $7^{\circ} 17^{\prime} .20^{\prime \prime} S$ and 37²3'.03”W, 27.IX.1997, fl., M.F. Agra; S. Cabral; R. A. Pontes; G. Baracho \& E.A. Rocha 4358 (JPB); Patos, $7^{\circ} 02^{\prime} .20^{\prime \prime}$ S and 37 $26^{\prime} .43$ ' W, 10.VII.2012, fr., D.S. Lucena; C. D. Ferreira; P. C. Souto.(6018 CRST); Patos, $7^{\circ} 02$ '.20"'S and $37^{\circ} 26^{\prime} .43$ 'W, 21.IX. 2011, M. Meneses (CSRT 002854); Pedra Lavrada, Serra da Flecha, 6 ${ }^{\circ} 23^{\prime} .50^{\prime \prime}$ S and $36^{\circ} 23^{\prime} .50^{\prime \prime} \mathrm{W}$, 30.IV.2007, est., B.I. Lima; P.C. Gadelha-Neto; R.J. Lima \& S.A. Melo (JPB 37012); Pico do Jabre, $7^{\circ} 17^{\prime} .20^{\prime \prime S}$ and 37 $23^{\prime} .03$ 'W, 23.IX.2003, M.M. Medeiros 40 (JPB); Pocinhos, $7^{\circ} 03^{\prime} .20^{\prime \prime S}$ and $36^{\circ} 05^{\prime} .29^{\prime \prime} \mathrm{W}$, 31.X.2007, fl., P.C. Gadelha-Neto \& B.I. Lima s.n. (JPB 38.069); Ibidem, Bela Vista, 36 14 '.15”W, 04.IX.2016, fl., S.S. Figueiredo 31 (HACAM); Ibidem, Sítio Bravo, 703'20”S and 3605'29”W, 19.X.2015, fl., S.S. Figueiredo 06 (HACAM); 15.XII.2016, fl., S.S. Figueiredo 10 (HACAM); 24.I.2016, fr., S.S. Figueiredo 13 (HACAM); Puxinanã, Sítio Espinheiro, 708'.57'S and 35 50'.02'W, 27.VIII.2016, S.S. Figueiredo 27 (HACAM); 29.X.2016, fr., S.S. Figueiredo 36 (HACAM); Ibidem, Várzea Salgada, 708'57'S and 35 50'02"W, 16.X.2015, fl., S.S. Figueiredo 05 (HACAM); 16.VIII.2016, fl., S.S. Figueiredo 24 (HACAM); 12.IX.2016, fr., S.S. Figueiredo 33 (HACAM); São João do Cariri, Pai Mateus, $7^{\circ} 23$ '36.82”'S and 36²18'09.96”W, 22.XII.1997, fl., C. Schlindwein 838 (JPB); Seridó, 6 54'.55"S and 36 27'.00'W, 13-IX-2005, fl., M.F. Agra; V.P.M. Coelho \& I.J.L. Diniz 6529 (JPB); Serra Branca, Cacimba Nova, 7³3'18”'S and 3640'56”'W, 28.VIII.2016. fl., S.S. Figueiredo 28 (HACAM); Serra da Raiz, Sítio Boa Ventura, 642'.14”S and 35²7'.25”W, 07.I.2012, fl., J.N.P. Cordeiro 43 (EAN); Solânea, 6 44'.26”'S and 35'43'.24”'W, 02.VIII.2001, fl., T.M. Grisi Velôso 271 (IPA); Teixeira, 7²13'14.85”'S and $37^{\circ} 15^{\prime} 08.37^{\prime}$ 'W, 15.IX.1984, fl., W.N. Fonseca 429 (RB).

Ceiba glaziovii (Figure 3 and 4) is a Brazilian endemic species from the northeastern region, in the states of Bahia, Ceará, Paraíba, Pernambuco, Rio Grande do Norte and Sergipe (Flora do Brasil 2020 in preparation). The species can be easily recognized especially for presenting aculeate stems with, a protuberance in the middle region, five stamens, and by the white petals with lilac to pink macule sparsely arranged on the inner surface. This species had already been registered in the Caatinga vegetation of the study area; however, during the execution of this work, it was also recorded under the Atlantic Forest domain, which represents a new occurrence for this environment (Figure 5). In the study area, it was found flowering in January and from May to December, and fruiting in November.

\section{Eriotheca Schott \& Endl., Melet. Bot.: 35. 1832.}

Eriotheca comprises 25 species restricted to South America (Duarte 2015). In Brazil, the species occur from the North to the South, associated with the Caatinga, the Cerrado, the Amazonian, and the Atlantic Forest, in deciduous, Seasonal and Ombrophiles forests, and in igapós (Flora of Brasil 2020 in preparation). It is characterized by stems without aculeous, leaflets with entire margin and slightly 


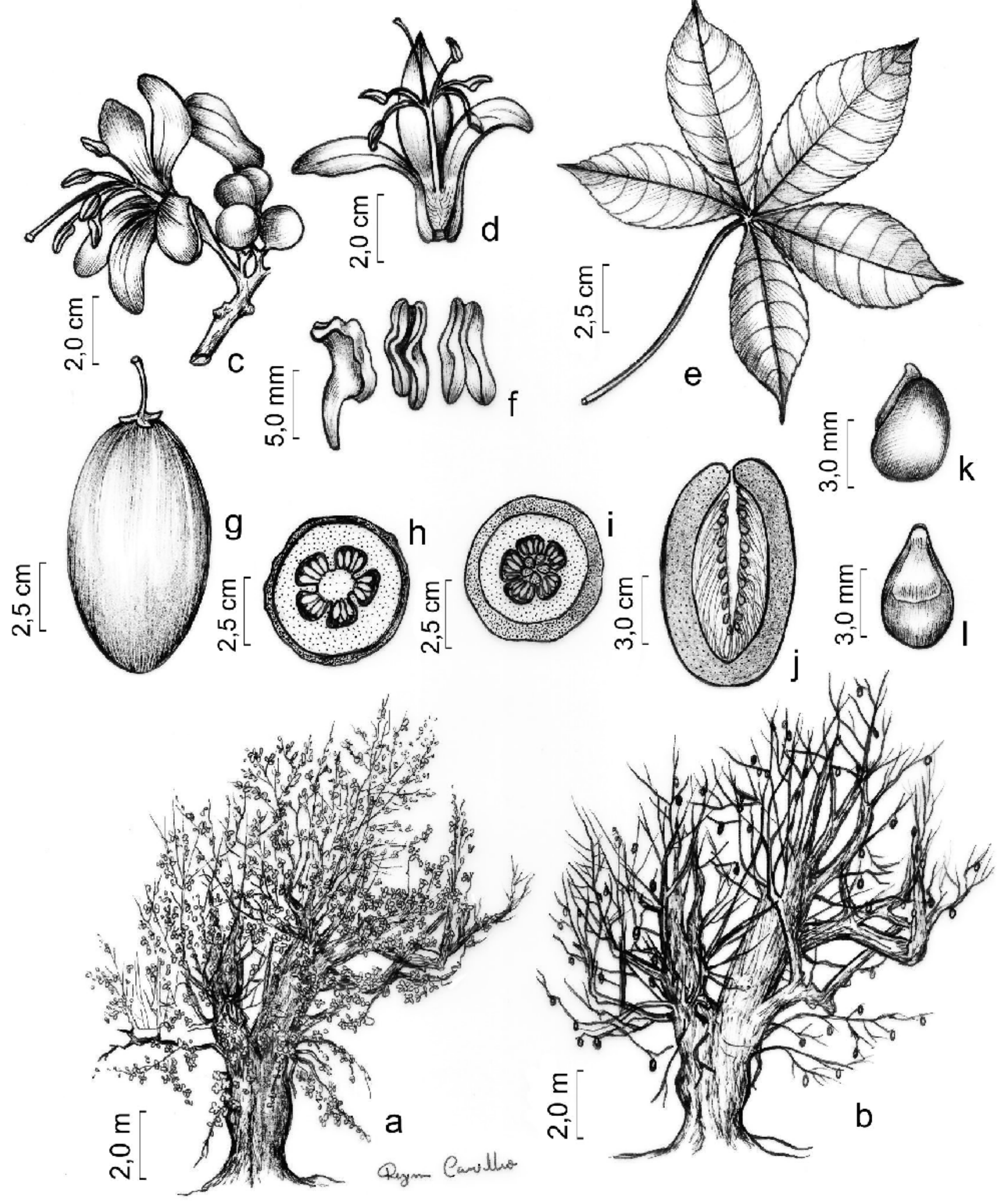

Figure 3. Ceiba glaziovii. a. individual in flowering; b. individual fruit; c. flower and flower bud; d. stem tube; e. leaf; f. anthers; g. fruit; h. ovary; i. ovary demonstrating the nectariferous glands; $\mathrm{j}$. fruit open; $\mathrm{k}-1$. seeds. 


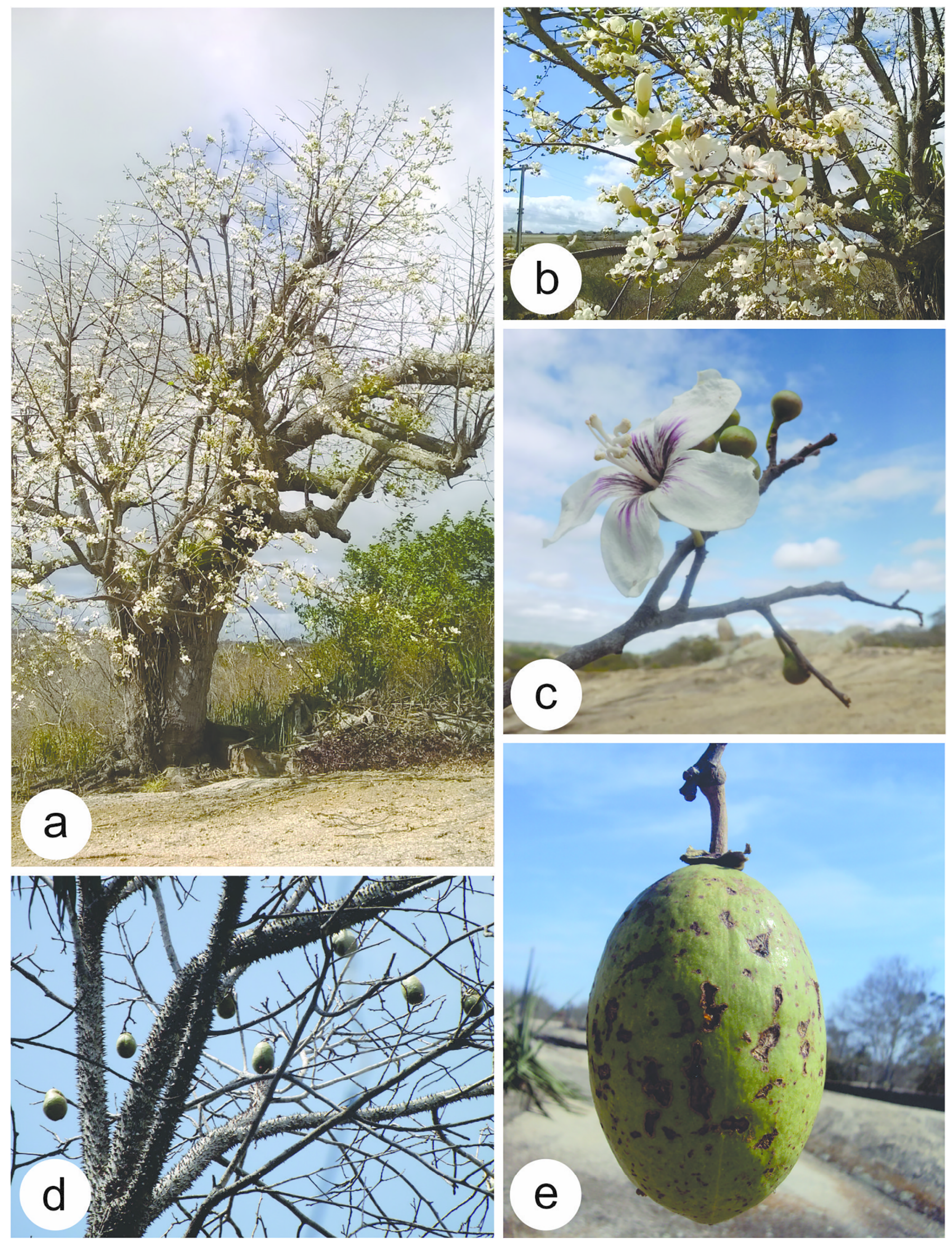

Figure 4. Ceiba glaziovii. a. habit; b. inflorescence; c. flower; d. fruiting; e. fruit (Photos: a, b, e. Figueiredo, S.S.; c-d. Monteiro, F. K. S.). 


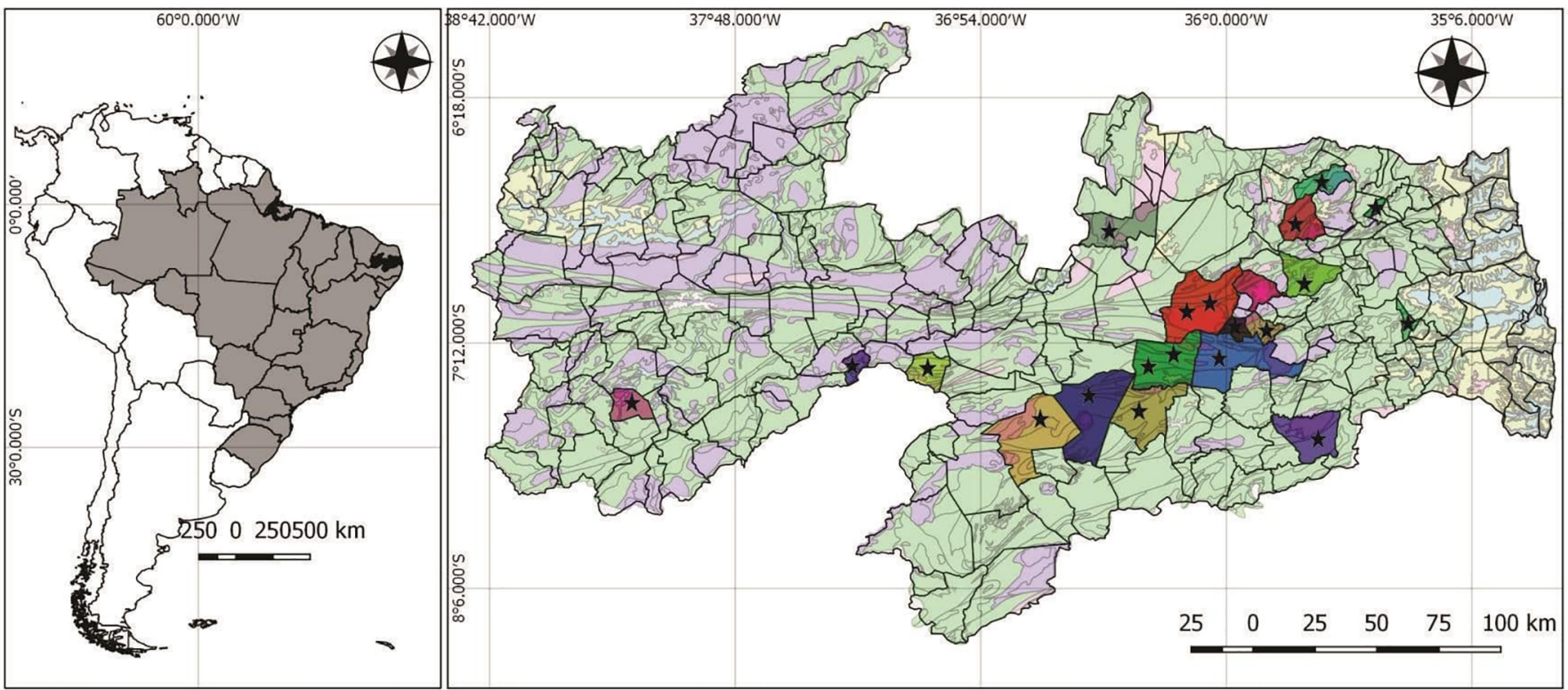

Subtitle

South America

Brazil

\section{Municipalities}

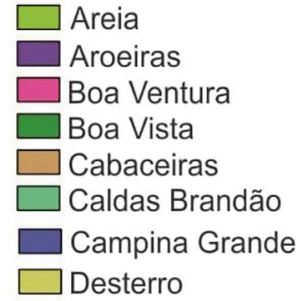

$\square$ Dona Inês
$\square$ Esperança
$\square$ Lagoa Seca
$\square$ Maturéia
$\square$ Pedra Lavrada
$\square$ Pocinhos
Puxinanã
São João do Cariri

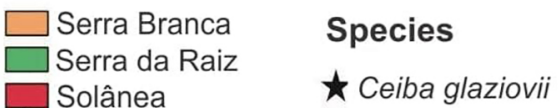

Ceiba glaziovii

Figure 5. Distribution of Ceiba glaziovii in the State of Paraíba, Brazil (Map: Rodrigues, E.M.).

revolute, inflorescences with $1-10$ cimes, receptacle with or without nectaries, indumentum lepidote, peltiform scales, starred trichomes, fruits capsules, obovoid, abundant wool, and numerous glabrous seeds (Duarte 2010, Carvalho-Sobrinho 2013). Two species were found in Paraíba: E. gracilipes and E. macrophylla, both associated with the Atlantic Forest vegetation.

\subsection{Eriotheca gracilipes (K. Schum.) A. Robyns, Bull. Jard. Bot. l'état} 33 (1/2): 145. 1963.

Trees, 3-17 m high; rectilinear stem, streaks absent, glabrescent. Stipules absent. Compound digitate leaves, 5-foliolate, pedicel ca. 1-3 cm long, leaflets 6-18 $\times 2-5 \mathrm{~cm}$, lepidote, coriaceous, obovate, truncated apex, cuneate base, entire margin, slightly revolute, main vein protruding at the abaxial face, craspedodromous venation, secondary veins $10-15$, evident, printed on abaxial face, glabrescent; petiole 3-27 cm long, with brown scales. Obovoid flower buds, axillary flowers, $1-5$ in each cyme, $12-13 \mathrm{~cm}$ long, peltate brown scales, sparse, receptacle with nectaries forming a continuous ring, calyx $0.6-1.0 \mathrm{~cm}$ long, cupuliform, truncated, 5-slightly apiculate, externally lepidote-brown, internally not seen; corolla $1-1.8 \mathrm{~cm}$ long, narrow-obovate, acuminate apex, curved, both sides covered with starred trichomes, golden; petals cream to yellowish; staminal tube $3-5 \mathrm{~cm}$ long, constricted at the median portion until the base, stamens 110-160, longitudinal fillaments $3 \mathrm{~cm}$ long, anthers $0.05-0.1$ $\mathrm{cm}$ long, reniform; ovary conic to subglobose, with peltate scales, 5-locules, pluriovulate; stylus $1-1.5 \mathrm{~cm}$ long. Capsule 4.0-7.0 $\times$ $2.0 \mathrm{~cm}$, obovoid, dehiscent, 4-5 valves, acuminate to apiculate, base rounded, valves $0.5-1 \mathrm{~cm}$ long, glabrescents, coppery wool. Seeds not seen.

Specimens examined: BRAZIL. PARAÍBA: Cruz do Espírito Santo, Engenho São Paulo, 706'37.14" S and 3505'42.93" W, 22.XI.1968, A. Lima 68-5491 (IPA).

Additional specimens examined: BRAZIL. DISTRITO FEDERAL: $15^{\circ} 48^{\prime} 45.12$ "S and $47^{\circ} 58^{\prime} 42.86^{\prime \prime W}$, 25.IX.1989, fr., D. Alvarenga 466 (RB). GOIÁS, Pirenópolis, $15^{\circ} 51^{\prime} 05.15^{\prime}$ 'S and 4857'30.83" W, 01.VIII.1984, fl., B.A.S. Pereira et al. 1102 (CEPEC); São Domingos, 16³4'40.85'S and 49²0'01.33"W, 13.VIII.1995, fl., B.A.S. Pereira \& D. Alvarenga 2840 (RB).

Eriotheca gracilipes (Figure 6) occurs in Bolivia and Brazil (Tropics 2018). In Brazil, it is recorded in the North (Rondônia), Northeast (Bahia, Paraiba and Pernambuco), Midwest (Distrito Federal, Goiás, Mato Grosso do Sul, Mato Grosso) and Southeastern (Minas Gerais, São Paulo) regions (Flora do Brasil 2020 in preparation). This species represents a new record for Paraiba and inhabits the Atlantic Forest vegetation (Figure 7). Additional material from the state of Pernambuco was also found during the morphological analyses. Eriotheca gracilipes is mainly characterized by the lcoriaceous leaflets, obovoid flower buds, and by the externally lepidote calyx. In the study 
area, it was found flowering in August and November, and fruiting in November.

2.2. Eriotheca macrophylla (K. Schum.) A. Robyns, Bull. Jard. Bot.l'état 33 (1/2): 152. 1963.

Trees, 10-20 m high; rectilinear stem, streaks absent, glabrescent, stipules absent. Compound leaves, digitate, 5-leaflet; petiole 2-15 mm long, leaflets 7.5-18 $\times 3.3-6.0 \mathrm{~cm}$, lepidote, carthaceous, large-obovate to oblong, rounded apex, emarginate, decurrent base, entire margin, slightly revolute, with abundant peltate trichomes on the abaxial face, and peltate trichomes scarce on adaxial face, craspedodromous venation, main vein salient on abaxial face, secondary veins evident, printed on abaxial face. Oblong flowers buds, flowers axillary, 2-7 in each cyme, $2.5-3.0 \mathrm{~cm}$ long, pedicel $1-3.0 \mathrm{~cm}$ long, glabrescents, receptacle with
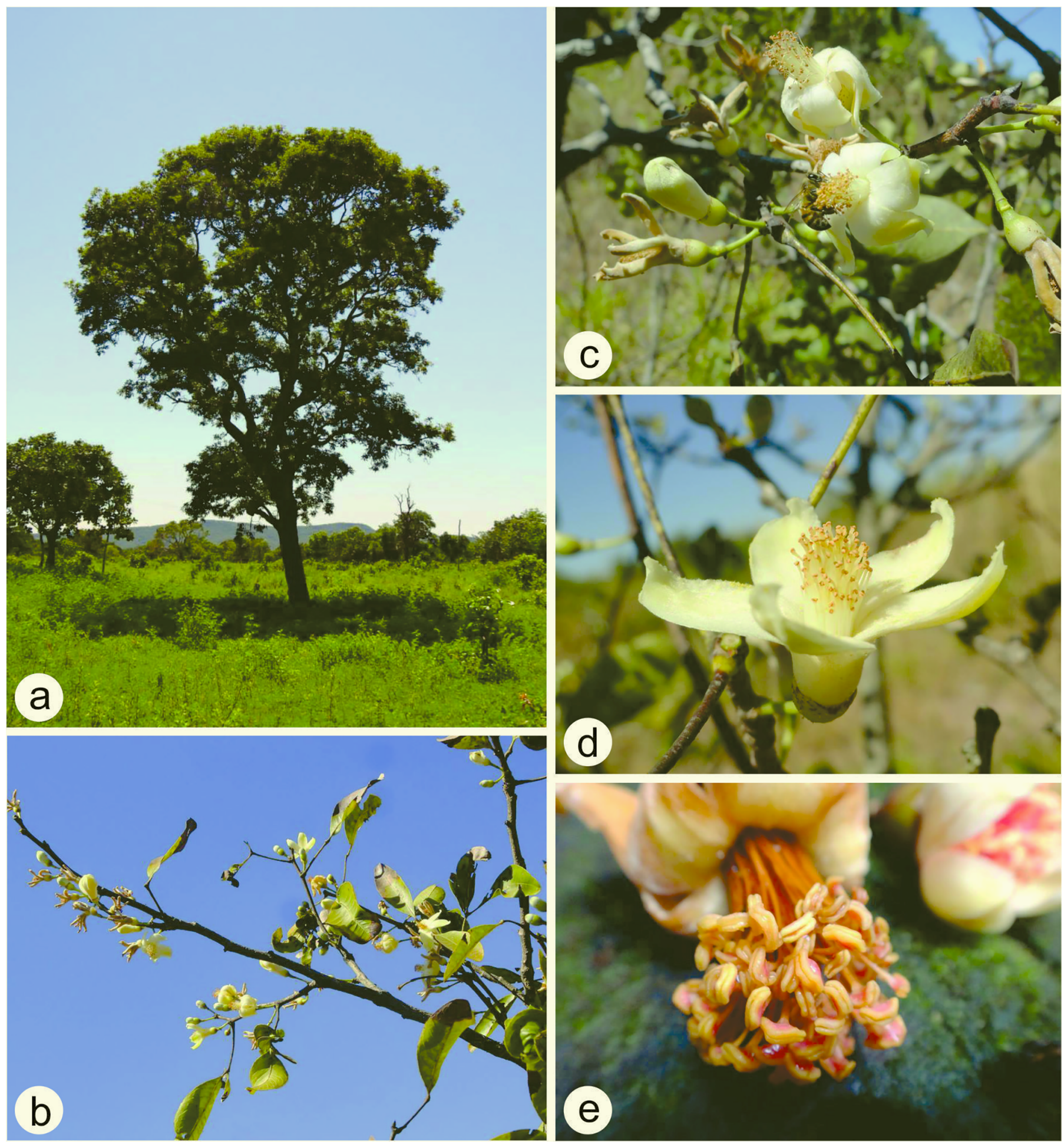

Figure 6. Eriotheca gracilipes. a. habit; b. branches; c. inflorescence; d. flower; e. stamens (Images: a. Nascimento, W.P.; b, c, d. Beneli, A.; e. Penati, R.) 


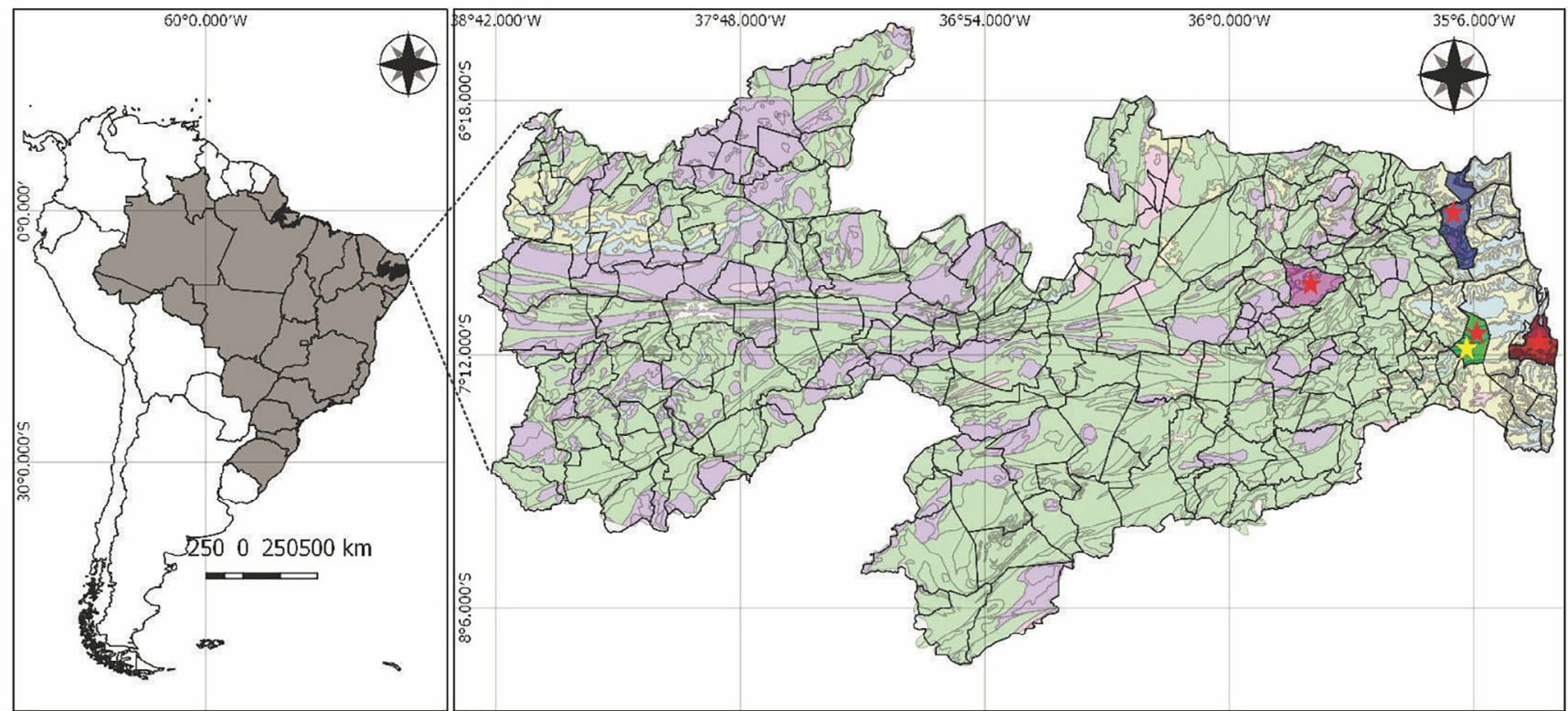

Subtitle

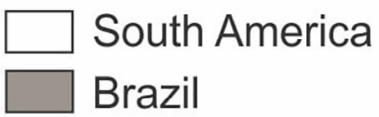

Municipalities

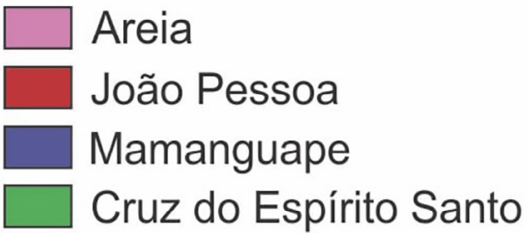

Species

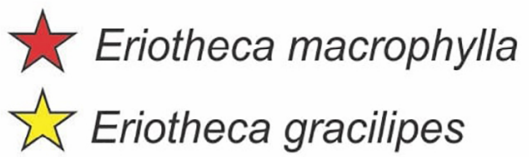

Figure 7. Distribution of the Eriotheca species found in the State of Paraíba, Brazil (Map: Rodrigues, E.M.).

or without nectaries, calyx $0.5-0.9 \mathrm{~cm}$ long, cupuliform, crenate margin, externally with flocculent trichomes, ferrugineous, internally not seen, petals $2.0-3.0 \mathrm{~cm}$ long, bright yellow, concave, obovate, rounded apex, recurved in the apical portion unilaterally, both sides covered with golden starred trichomes; staminal tube $0.4-0.5 \mathrm{~cm}$ long, constricted in the median portion to the base, 100-120 stamens, longitudinal fillaments $0.8-1.8 \mathrm{~cm}$ long, anthers $0.05 \mathrm{~cm}$ long, reniform; ovary globose to subglobose, flocculent coppery scales, 5 carpels, 5 locules, pluriovulate, stylus $1.3 \mathrm{~cm}$ long with flocculent coppery trichomes in the basal portion. Capsule 4.0-6.0 $\times 0.5-1 \mathrm{~cm}$, obovoid, 5 valvate, acuminate, cuneate base, valves $2.0-3.0 \mathrm{~cm}$ long, glabrescent, abundant wool, brownish seeds not seen.

Specimens examined: BRAZIL. PARAÍBA: Areia, Mata do Pau Ferro, 6 658'.15"S and 35'44'.58”'W 12.VII.2001, E. Cunha 30144 (JPB); João Pessoa, 707'13.31'’S and 34 50'42.67''W, 23.XI.1979, M.F. Agra 200 (JPB); Ibidem, 707'13.31'S and 34'50'42.67'W,18.V.1993, fr., P. C. Gadelha-Neto 27 (JPB); Mamanguape, 6 50 '22.95”'S and 3508'0814"W, 22.XI.1991, L.P. Félix \& C.A.B. Miranda 4592 (EAN); Ibidem, Estação Ecológica do Pau Brasil, 6³6'15.30”S and 3507'45.36”'W, 06.I.2008, fr., S. Satyro \& M.S. Pereira 40542 (JPB).

Additional specimens examined: BRAZIL. PERNAMBUCO: São Lourenço da Mata, Estação Ecológica do Tapacurá, 802’27.54”S and 35¹1'46.51'W, 17.VIII.2001, K. Almeida 184 (JPB).

Eriotheca macrophylla is endemic from Brazil, occurring in the Northeast (Alagoas, Bahia, Pernambuco and Paraíba) and Southeast (Espírito Santo, Minas Gerais and Rio de Janeiro) regions, associated with the Atlantic Forest domain (Flora do Brasil 2020 in preparation). This species is a new record for the State of Paraíba (Figure 7) can be easily recognized by the carthaceous leaflets; oblong flower buds, and the externally flocculent ferrugineous trichomes on the calyx. In the study area, it was found with flowers in June and with fruits in May, July and August.

\section{Pseudobombax Dugand, Caldasia 2(6): 65. 1943.}

This genus has 23 species, restricted to the Neotropical region (Duarte 2015). In Brazil, the species can be found in all the regions, inhabiting Ombrophylous forests, Semideciduous forests, Restinga, Caatinga, Cerrado, rocky field and ciliary forest, including in rocky outcrops (Flora do Brasil 2020 in preparation).

It is morphologically characterized by presenting the stem with green longitudinal streaks, which are spread throughout the plant, compound leaves and unifoliolate, polystemone flowers, bithecae, fruit a 5-valvate capsul, abundant wool and numerous seeds, reniform (CarvalhoSobrinho \& Queiroz 2010). In Paraíba, it is represented by three species: Pseudobombax marginatum, P. parvifolium and P. simplicifolium, associated with the Caatinga vegetation (Agreste and Sertão).

3.1. Pseudobombax marginatum (A.St.-Hil., Juss. \& Cambess.) A. Robyns, Bull. Jard. Bot. l'État 33(1): 73. 1963.

Trees, 5-8 m high; large canopy. Irregular stem with amorphous excrescences, glabrescent, with yellowish-green longitudinal streaks. Stipules absent. Compound leaves, digitate, petiole 7.0-11.0 mm long, 5-7 foliolate, grouped at the apex of the branches, without braquiblasts; 
leaflets $6.5-14.5 \times 4.0-8.1 \mathrm{~cm}$, oblong-elliptical to elliptical, carthaceous, acuminate to obtuse apex, base cuneate and slightly attenuate, entire margin, adaxial face glabrous, face abaxial pubescent with branched trichomes under the vein, main vein salient on the abaxial face, secondary veins prominent, printed on the abaxial and adaxial face, craspedodromous venation. Terminal or subterminal flowers, solitary, $11-17.3 \mathrm{~cm}$ long, oblong to oboval buds, pedicel $2.0-3.0 \times 0.4 \mathrm{~cm}$, glabrous, glands in the pedicel connection with the calyx $2.3 \times 2.5 \mathrm{~cm}$, cupuliform to campanulate, truncated, inconspicuously 5-apiculate, externally with simple microtrichomes, internally glabrous; petals $12-14.8 \times 1.5-2.0 \mathrm{~cm}$, linear-lanceolate, acute apex, brown externally and sometimes with simple trichomes, internally white, pubescents, covered with simple trichomes; staminal tube $2.0 \times 0.8 \mathrm{~cm}$, glabrous, stamens fused only at the base of the tube and then free among each other; stamens 300-350, longitudinal fillaments free 10-11 × 3.5-4.0 $\mathrm{cm}$, anthers $0.3-0.4 \mathrm{~cm}$ long, bithecae; ovary $5 \mathrm{~mm}$ long, oblong, subglabrous except for peltate microtrichromes, 5-locules, pluriovulate; stylus $14.5 \mathrm{~mm}$ long, glabrous. Capsule $13-15 \times 4.0-6.0 \mathrm{~cm}$, oblongoid, 5-valvate, apiculate apex, cuneiform base, valves $0.8-1.3 \mathrm{~cm}$ diam, glabrous, abundant gold wool. Seeds $0.5-0.6 \mathrm{~cm}$ long, piriform, light brown when immature and blackened when herborized.

Specimens examined: BRAZIL. PARAÍBA: Boqueirão, 7²8'36.94'S and 3607'56.28”'W, 22.VI.2011, I.V.P. Nóbrega 253 (CSTR); Campina Grande, INSA, 7014'.34"S and 35 $54^{\circ} .05^{\prime \prime} \mathrm{W}$, 24.I.2011, A.S. Barbosa 1972 (EAN); Ibidem, INSA, 7¹4'.34”S and $35^{\circ} 54^{\prime} .05^{\prime}$ 'W, 13.III.2012, fl., A.L.S. Albuquerque \& D.S. Ferraz (EAN 19.617); Congo, 7²8'.33"S and 36 39'.01"W, 01.IX.2011, fl., s.c. (EAN 17.562); C.E.L. Lourenço; M.C. Pessoa \& G.A. Costa 836 (JPB); Diamante, Fazenda Andresa, 7²5'21.33"S and 38 $15^{\circ}$ '44.41"W, 02.V.2011, C.E.F. Diniz 2080 (CSTR); João Pessoa, Fazenda Santana, Sítio João do Cariri, 7²8'.33”S and 36²8'.55”W, 21.V.1997, R.G. Luna 01 (JPB); Patos, $7^{\circ} 01^{\prime} .28^{\prime \prime}$ S and $37^{\circ} 16^{\prime} .48^{\prime \prime} \mathrm{W}, 21 . \mathrm{VI} .2014$, fl., H.O. Machado-Filho 460 (IPA); Itaporanga, Fazenda Cafula e Lagoa, $7^{\circ} 18^{\prime} 13.28^{\prime \prime}$ S and 3809'00.64'W, 21.IX.2014, P.F. Souza 43 (CSTR); Patos, Santa Terezinha, $7^{\circ} 02^{\prime} .20^{\prime \prime}$ S and $37^{\circ} 26^{\prime} .43^{\prime \prime W}, 25 . I I I .1993$, fl., M.F. Agra; E.A. Rocha; E. Locatelli et al. \& A.B. Fragoso 1729 (IPA); Pocinhos, Sítio Icó, $07^{\circ} 17^{\prime} .015^{\prime \prime}$ S and $036^{\circ} 16^{\prime} .567^{\prime \prime} \mathrm{W}, 16 . \mathrm{IX} .2007$, fl., L.E.T. Mendonça 34 (JPB); Ibidem, 74'28.39'S and 36 $03^{\circ}$ '18.65' 'W, 21.VI. 211, I.V.P. Nóbrega, (2705 CSTR); Poço Dantas, Olho D’Água do Frade, 6²4'14.78"S and 38²9'47.98'W, 12.X.2007, I.B. Lima \& P.C. Gadelha-Neto; J.R. Lima; C.E.L. Lourenço; M.C. Pessoa \& G.A. Costa 836(JPB); Riacho dos cavalos, 6'26'08.51'S and 37'39'07.08'W, 04.II.2014, fl., R.H. Silva (5959 CSTR); Santa Teresinha, 702'.20”S and $37^{\circ} 26^{\prime} 43$ "W, 24.VII.2013, A.E.S. Ferreira (4720 CSTR); Ibidem, 18.IV.2006, C.M.A. Pegado \& L.P. Félix 08 (EAN); São João do Cariri, Estação Experimental, $7^{\circ} 28^{\prime} .33$ ”S and 36 $28^{\circ} .55^{\prime \prime} \mathrm{W}, 25 . \mathrm{VIII} .1993$, fl., C.M.L. Aguiar 35 (JPB); Ibidem, Riacho Aveloz, 7²8'.33”S and $36^{\circ} 28^{\prime} .55^{\prime \prime W}$, 18.VIII.2004, fl., A.V. Lacerda \& F.M. Barbosa 225 (JPB); Ibidem, Riacho Gangorra, 7² $28^{\prime} .33^{\prime \prime S}$ and $36^{\circ} 28^{\prime} .55^{\prime \prime} \mathrm{W}$ 20.XII.2004, A.V. Lacerda \& F.M. Barbosa 286 (JPB); Ibidem, Riacho Salgado, 29.IX.2004, A.V. Lacerda \& F.M. Barbosa 222 (JPB); Ibidem, 22.VII.2005, A.V. Lacerda \& F.M. Barbosa 495 (JPB); Ibidem, Riacho Aveloz, $7^{\circ} 28^{\prime} .33^{\prime \prime S}$ and $36^{\circ} 28^{\prime} .55^{\prime \prime} \mathrm{W}$ 26.IX.2005, fl., A.V. Lacerda
\& F.M. Barbosa 509 (JPB); São José do Bonfim, Sitio Pé de Serra, $7^{\circ} 08^{\prime} .43$ "S and $37^{\circ} 18^{\prime} .59^{\prime \prime} \mathrm{W}, 13 . \mathrm{VII} .2001$, fl., M.G.V. Marinho 17 (JPB); São Mamede, $6^{\circ} 55^{\prime} .26^{\prime}$ 'S and $37^{\circ} 05^{\prime} .02^{\prime \prime} \mathrm{W}$, 10.IX.2011, fl., s.c. (EAN 20.484); São José de Piranhas, $7^{\circ} 07^{\prime} 08.10^{\prime}$ 'S and 38 29'57.70”W, 5.VII.2011, P.F. Souza 26 (CSTR); Serra Branca, Serra do Jatobá, $7^{\circ} 33^{\prime} .18^{\prime}$ 'S and 36 $42^{\circ} .56^{\prime \prime}$ 'W, 29.VI.016, S.S. Figueiredo 17 (HACAM); Ibidem, 21.VII.2016, fl., S.S. Figueiredo 19 (HACAM); Ibidem, 04.VIII.2016. fl., S.S. Figueiredo 23 (HACAM); 09.IX.2016, fr., S.S. Figueiredo 32 (HACAM); Sousa, Fazenda Jangada, 645'.09'S and $38^{\circ} 13^{\prime} .27^{\prime \prime} \mathrm{W}, 2 . I I I .1995$, fl., P.C. Gadelha-Neto 205 (JPB); Ibidem, Vale dos Dinossauros, 645'.09"S and 38 13 '.27'W, 06.VIII.2004, P.C. Gadelha-Neto 1220 (JPB); Sumé, Sítio Gonçalo, $7^{\circ} 39^{\prime} .44^{\prime}$ S and 36 54'.21'W, 12.VI.1999, F. Barbosa 24 (JPB).

Pseudobombax marginatum (Figure 8 and 9 h-n) occurs in Peru, Bolivia and Brazil, specifically in the North, Northeast, Midwest, Southeast, and South regions, under the domain of the Caatinga, Cerrado and Atlantic Forest, including the Seasonal Deciduos Forest (Flora of Brasil 2020 in preparation). The species is easily recognized by the irregular stem with amorphous excrescences and yellowish-green longitudinal streaks. In the study area (Figure 10), it was found flowering in March, June, and from August to November and fruiting in November.

3.2. Pseudobombax parvifolium Carv. -Sobr. \& L.P. Queiroz, Novon 20(1): 17-19. 2010.

Trees, 8-12 m high; rectilinear stem, with dark green longitudinal streaks, glabrescent. Stipules absent. Compound leaves, digitate, pedicel $1.0 \mathrm{~cm}$ long, 5-7 foliolate, grouped at the apex of the branches, without braquiblasts; leaflets $8.0 \mathrm{~cm} \times 0.3 \mathrm{~cm}$, oval-lanceolate, carthaceous, elliptical, acuminate apex, cuneate base and slightly attenuated, revolute margin, irregularly crenulate, main vein salient on the abaxial face, 9-12 secondary veins, evident, printed on the abaxial face, glabrescent; craspedodromous venation; petiole $11 \mathrm{~cm}$ long. oblong-lanceolate buds. Terminal flowers, solitary, 10-17 cm long, curved; calyx $2.0 \mathrm{~mm}$ long, cupuliform to campanulate, truncated, sometimes inconspicuously 5-apiculate, externally puberulous with short trichomes, thick, internally sericeous on distal half; petals $12-15 \mathrm{~cm}$ long, white internally, linearlanceolate, apex acute to acuminate, externally brown, usually in longitudinal strips when herborized, tomentose at the base, internally pubescent; staminal tube 8.8-9 cm long, stamens 400-450, fused only at the base of the tube and then free among each other; longitudinal fillaments free $8.5 \mathrm{~cm}$ long, anthers $0.3 \mathrm{~cm}$ long, bithecae; ovary $0.5-0.6 \mathrm{~cm}$ long, ovoid, subglabrous except for peltate microtricomes, 5-locules, pluriovulate; style $13.5 \mathrm{~cm}$ long, subglabrous except for peltate microtrichome in the basal portion. Capsule 10-14 $\times 5 \mathrm{~cm}$, oblong to oblong-elliptic, 5-valves, apiculate, cuneiform base, valve $1 \mathrm{~cm}$ diam, glabrous, woody, light-brown to cream wool. Seeds $0.9 \mathrm{~cm}$ long, reniform, light to dark-brown.

Specimens examined: BRAZIL. PARAÍBA: Boa Vista, APA do Cariri, $7^{\circ} 18^{\prime} .07^{\prime \prime}$ 'S and $36^{\circ} 42^{\prime} .24^{\prime \prime} \mathrm{W}, 26 . X .2016$, fl., fr., S.S. Figueiredo 34 (HACAM); Pocinhos, Bela Vista, $7^{\circ} 03^{\prime} .20^{\prime \prime} \mathrm{S}$ and $36^{\circ} 05^{\prime} .29^{\prime \prime} \mathrm{W}$, 04.IX.2016, fl., S.S. Figueiredo 30 (HACAM); Ibidem, Bravo, $7^{\circ} 03^{\prime} .20^{\prime \prime}$ S and $36^{\circ} 05^{\prime} .29^{\prime}$ 'W, 16.XI.2015, fl., S.S. Figueiredo 07 (HACAM); Ibidem, 15.XII.2015, fr., S.S. Figueiredo 11 (HACAM); 24.I.2016, S.S. Figueiredo 15 (HACAM); Ibidem, 10.VII.2016, S.S. 
Figueiredo, S. S. et al.
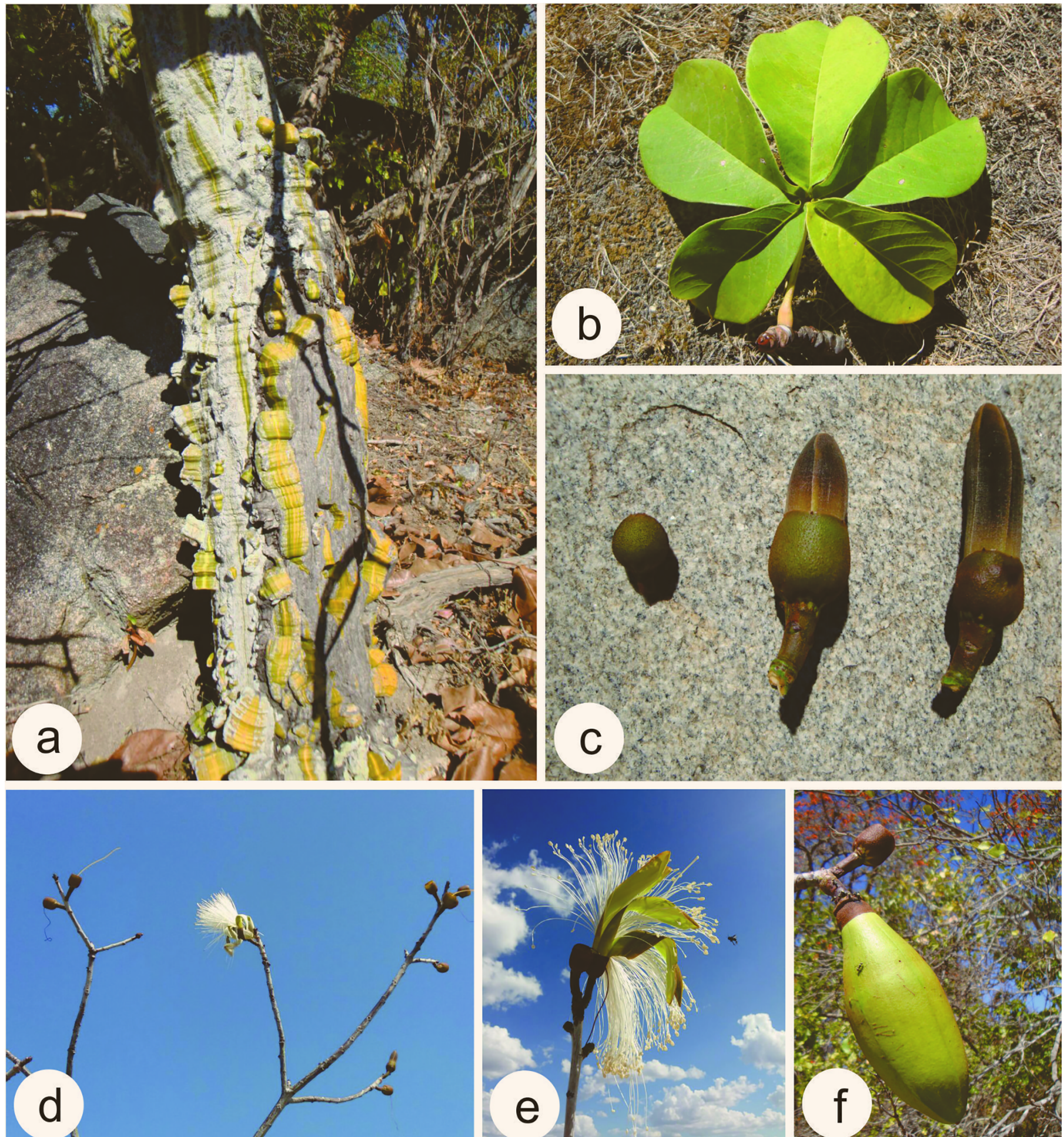

Figure 8. Pseudobombax marginatum. a. stem; b. leaf; c. flower buds; d. inflorescence; e. flower; f. fruit (photos: Monteiro, F.K.S.; F. Rodrigues, E.M.).

Figueiredo 18 (HACAM); Soledade, 0703'26'S and 36 $21^{\prime} .46^{\prime \prime} \mathrm{W}$, 04.VII.2006, R.F.P. Lucena \& G.R. Almeida 246 (PEUFR).

Pseudobombax parvifolium (Figure 9a-g and 11)is endemic from Northeastern Brazil, in the states of Bahia and Sergipe, inhabiting Caatinga environments (Flora do Brasil 2020 in preparation). It can be easily recognized by the rectilinear stem with dark-green longitudinal streaks and the reniform seeds. In the study area (Figure 10), it was found flowering from September to December, and fruiting in October and December. 
Flora of Paraíba: Bombacoideae

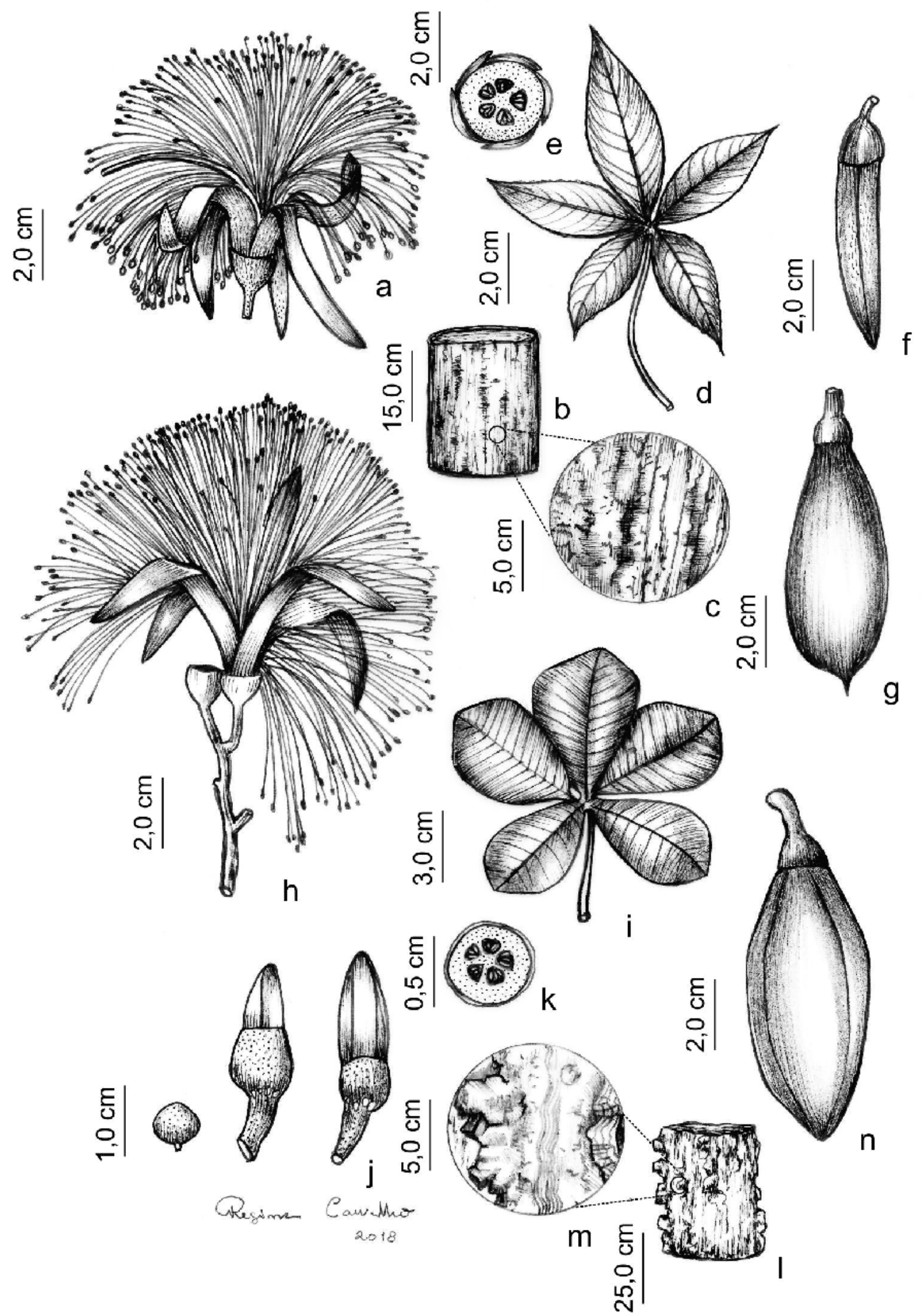

Figure 9. Pseudobombax parvifolium. a. flower; b. stem; c. streaks; d. leaf; e. ovary; f. flower bud; g. fruit. P. marginatum. h. flower; i. leaf; j. flower bud; k. ovary; 1. stem; m. streaks; $n$. fruit. 
Figueiredo, S. S. et al.

3.3. Pseudobombax simplicifolium A. Robyns, Bull. Jard. Bot. l'État 33: 81. 1963.

Trees, 6-12 m high; stem with irregular green rectilinear streaks. Triangular stipules, concave. 3-foliolate, united at the apex in braquiblasts, leaves and branches with peltate and dense microtrichome among each other; pedicel $16 \mathrm{~mm}$ long, leaflets $6-7 \times 1.0-1.1 \mathrm{~cm}$, oval-elliptic to oval-lanceolate, coriaceous, carthaceous, acute apex, base obtuse, margin revolute, glabrous on both sides, main vein salient, secondary and tertiary veins evident; craspedodromous venation; petiole $1.5 \mathrm{~cm}$ long. Oblong flower buds, terminal flowers, solitary or in groups with $2-3,10-11 \mathrm{~cm}$ long, sometimes striated longitudinally, glabrous; calyx $2.2 \times 1.1 \mathrm{~cm}$, campanulate, usually 5-apiculate, externally subglabrous due to sparse and peltate microtrichomes and internally, sericeous; petals $8-9 \times 0.7-0.8 \mathrm{~cm}$, brown when dry (not seen in nature), lanceolate, acute apex, with simple microtrichomes, internally sericeous; staminal tube $1.1 \mathrm{~cm}$ long, 200-300, stamens fused only at the base of the tube and then free among each other, glabrous; fillaments free $60-100 \mathrm{~mm}$ long, anthers $0.2-0.4 \mathrm{~cm}$ long; ovary $0.6 \times$ $0.2 \mathrm{~cm}$, oblong, glabrous, 5-locules, pluriovulate; style 7-12 cm long. Capsule $1.2 \times 0.7 \mathrm{~cm}$, oblong to obovoid, valves not observed, abundant light brown wool. Seeds $0.4-0.5 \mathrm{~cm}$ long, piriform, dark brown.

Specimens examined: BRAZIL. PARAÍBA: Aroeiras, $7^{\circ} 35^{\prime} .05^{\prime}$ 'S and 35\%42'.24”'W, 24.IX.1994, fl., M.F. Agra et al. 3298 (JPB).

Additional specimens examined: BRAZIL. BAHIA: Luiú, 14'24'45.96"'S and 43'33'16.58'"W, 16.VII.2005, fl., R.C. Forzza, B.R. Silva \& R. Dias-Melo 4065 (RB). BAHIA: Curaçá, Faz. Angical, 9¹5'40.48'S and 3943'38.44”'W, s.d., fr., S.B. Silva 303 (CEPEC).

Pseudobombax simplicifolium (Figure 12) is endemic from Brazil, occurring in the Northeast (Bahia, Pernambuco, Piauí, Sergipe) and Southeast (Minas Gerais) regions, associated with the Caatinga domain (Flora do Brasil 2020 in preparation). In this work, it is reported as a new occurrence for Paraíba and inhabits the Caatinga vegetation (Figure 10). Morphologically, P. simplicifolium is characterized by presenting 3-leaflets leaves united at the apex in braquiblasts. In the study area, it was found flowering in November.
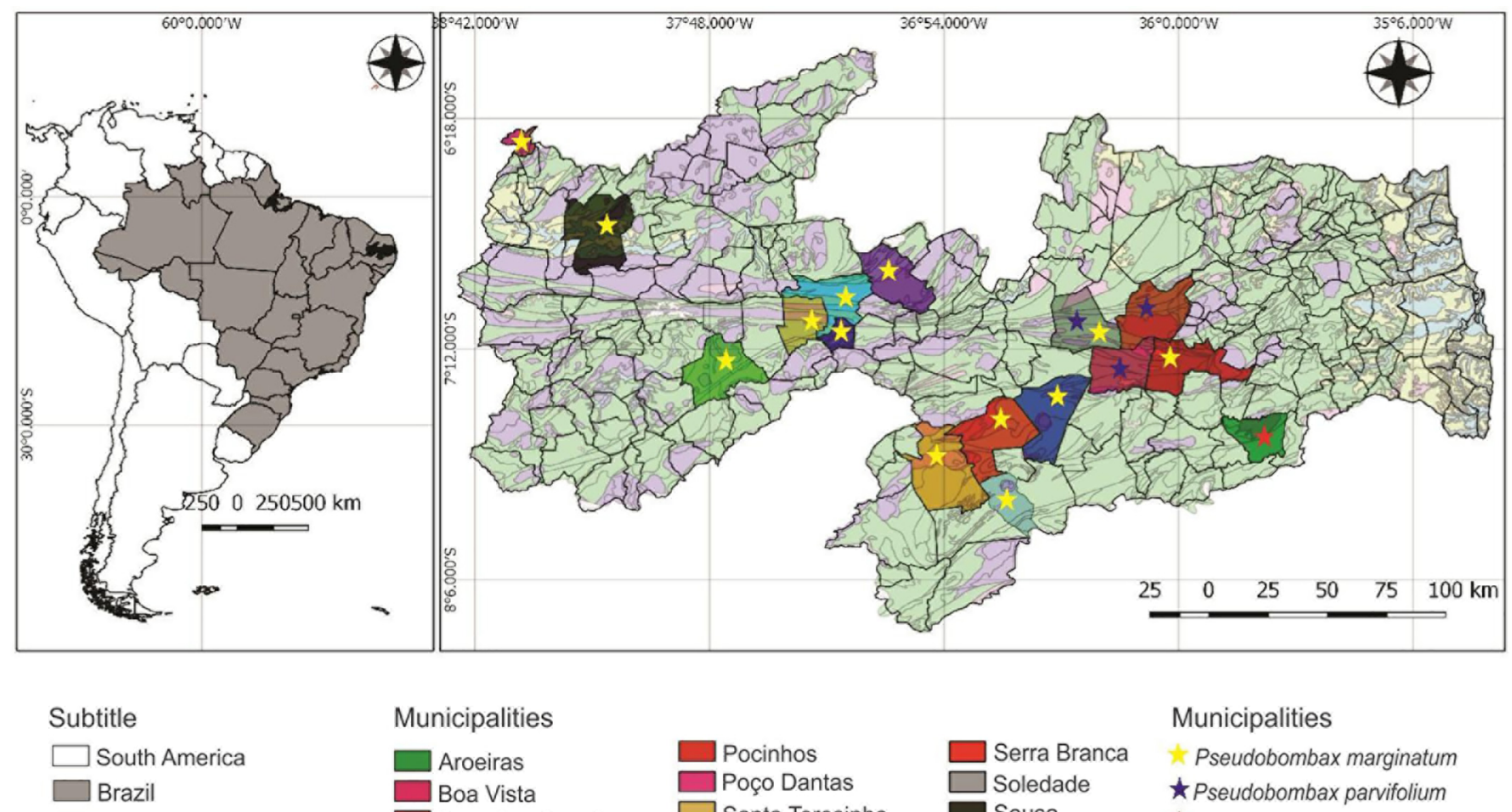

igure 10. Distributio
tp://www.scielo.br/b

Figure 10. Distribution of the species of Pseudobombax found in the State of Paraíba, Brasil (Map: Rodrigues, E.M.).

Municipalities
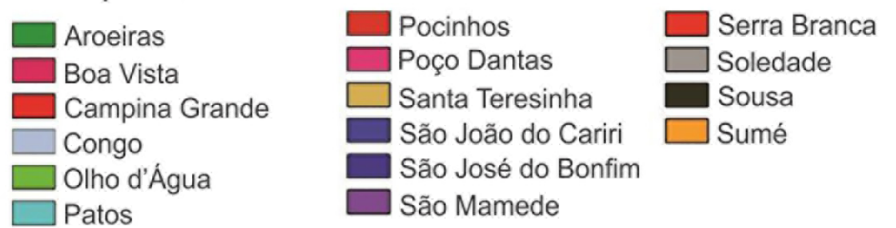

Municipalities

* Pseudobombax marginatum

$\star$ Pseudobombax parvifolium

$\star$ Pseudobombax simplicifolium 


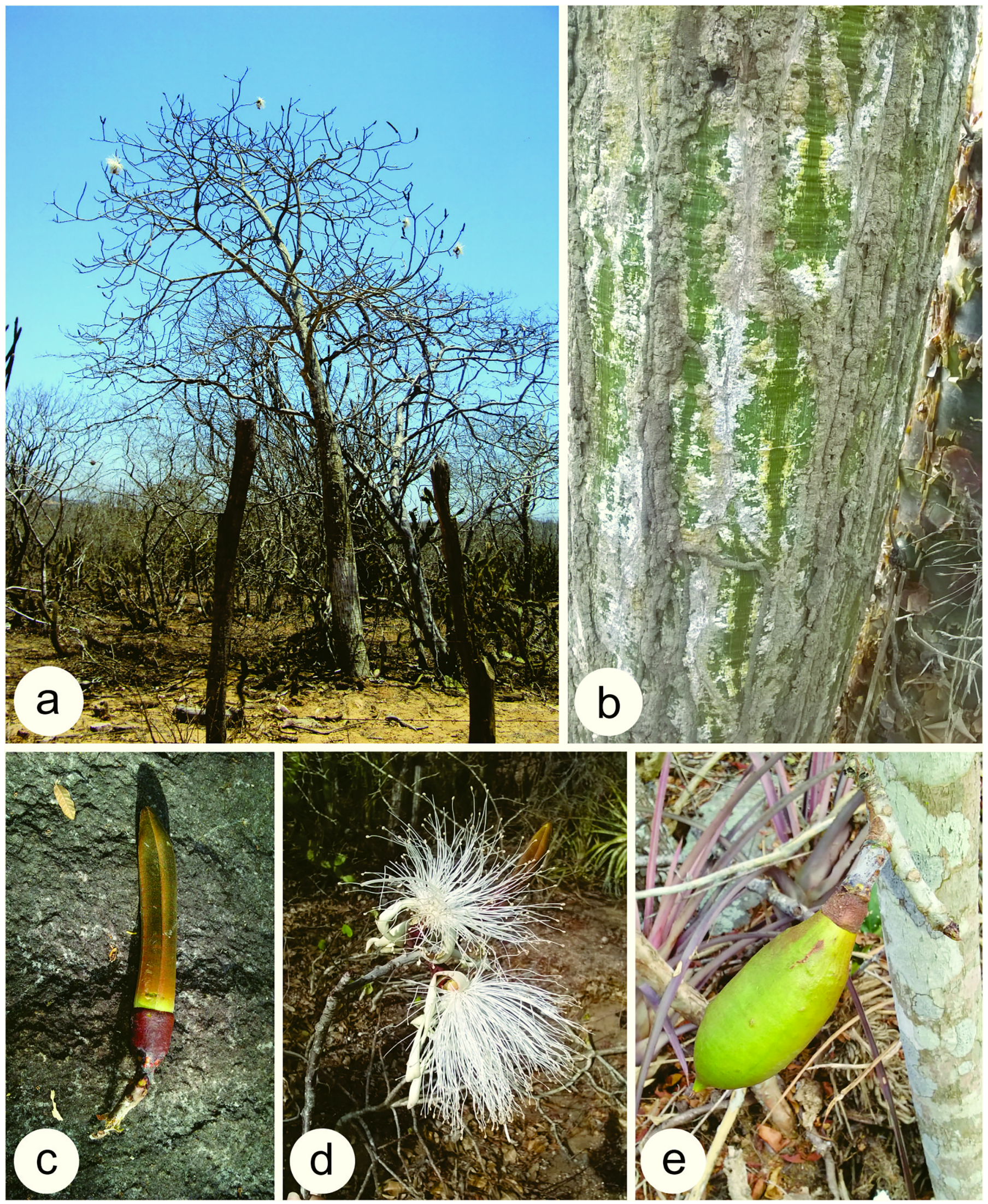

Figure 11. Pseudobombax parvifolium. a. habitat; b. stem; c. flower bud; d. flower; e. fruit (Photos: Figueiredo, S.S.). 

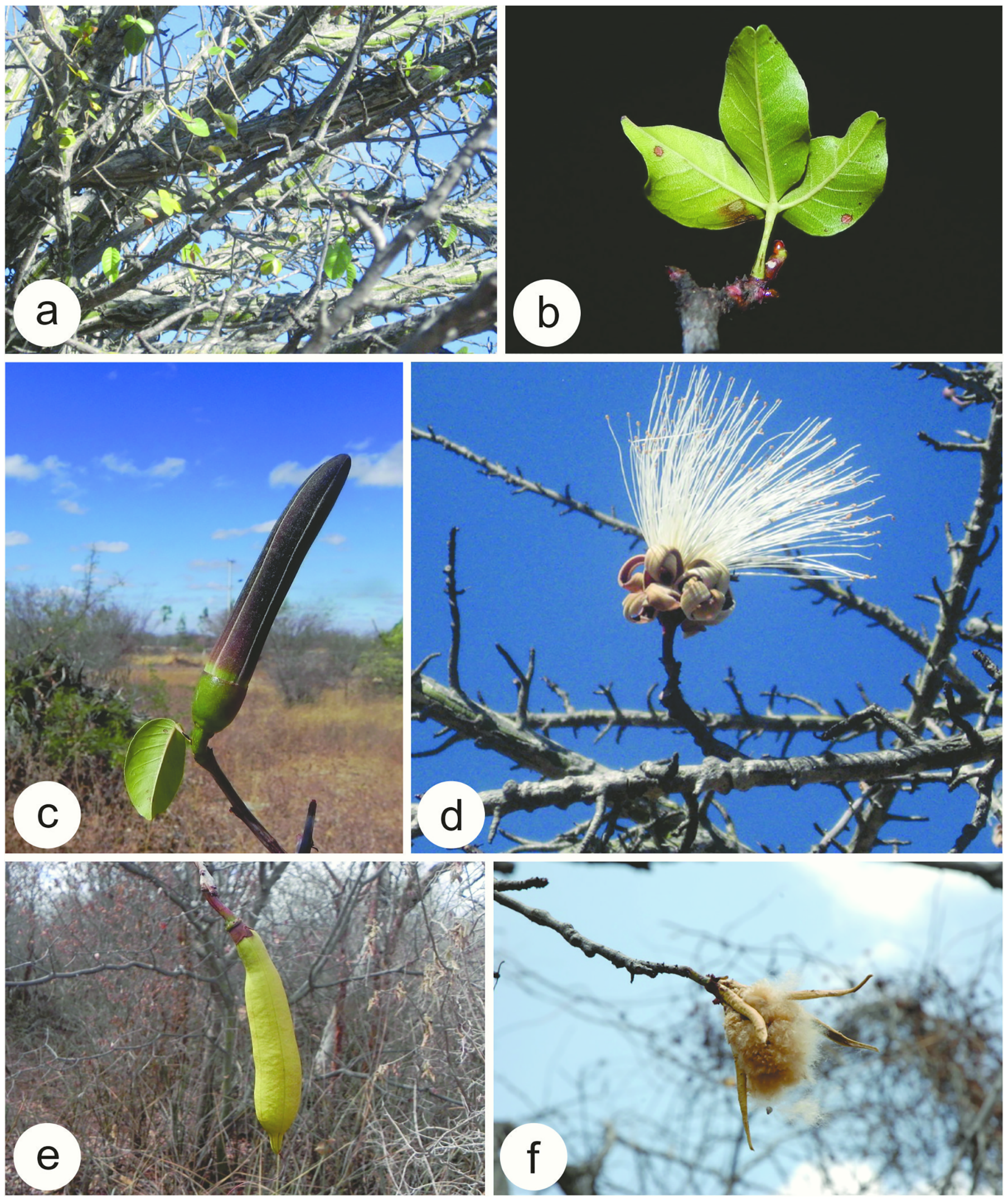

Figure 12. Pseudobombax simplicifolium. a. branches; b. leaf; c. flower bud; d. flower; e. fruit; f. kapok (photos: b-e. Carvalho-Sobrinho; a, f. Siqueira-Filho, J.A.) 


\section{Acknowledgements}

To the CNPq (National Scientific and Technological Development Council), by Scientific Initiation Scholarship granted to S.S. Figueiredo. The State University of Paraíba (UEPB), support for the development of this work. J.I.M. Melo thanks to the CNPq (National Scientific and Technological Development Council), for the Research Productivity Scholarship (PQ-2 Proc. n. 303867/2015-9). Regina Alcântara, by producing the illustrations in Nanjing. Erimágna de Moraes Rodrigues, for the production of the map.

\section{Authors contributions}

Sabrina Soares Figueiredo: conceived the idea and structured the manuscript; contributed to the wording of the text, and the interpretation of the results. She also conducted the fieldwork.

Fernanda Kalina da Silva Monteiro: contributed to the writing of the text, and the interpretation of the results.

José Iranildo Miranda de Melo: Structured the manuscript and identified some of the species of this work; contributed to the wording of the text and the interpretation of the results; contribution to critical review, adding intellectual content.

\section{Conflicts of interest}

The authors declare that they have no conflict of interest related to the publication of this work.

\section{Ethics}

This study doesn't involve dealing with humans.

\section{Data availability}

The data recorded in this work will be available in GenBank.

\section{References}

AGUIAR, C. 2012. Botânica para Ciências Agrárias e do Ambiente. Sistemática. Instituto Politécnico de Bragança 3:1-81.

ALVERSON, W.S., WHITLOCK, B.A., NYFFELER, R., BAYER, C. \& BAUM, D.A. 1999. Phylogeny of the core Malvales: evidence from ndhf sequence data. Am. J. Bot. 86(10):1474-1486.

APG. 1998. An ordinal classification for the families of flowering plants. Ann. Mo. Bot. Gard. 85: 531-553.

APG IV. 2016. An update of the Angiosperm Phylogeny Group classification for the orders and families of flowering plants: APG IV. Bot. J. Linn. Soc. 181:1-20.

BAUM, D.A., ALVERSON, W.S. \& NYFFELER, R. 1998. A durian by any other name: Taxonomy and nomenclature of the core Malvales. Harv. Pap. Bot. 3: 315-330.

BAYER, C., FAY, M.F., BRUIJN, A.Y., SAVOLAINEN, V., MORTON, C.M., KUBITZKI, K., ALVERSON, W.S. \& CHASE, M.W. 1999. Support for an expanded family concept of Malvaceae within a recircumscribed order Malvales: A combined analysis of plastid atpB and rbcL DNA sequences. Bot. J. Linn. Soc. 129(4):267-303.

BENTHAM, G. \& HOOKER, J.D. 1862. Bombacaceae. In Genera Plantarum, London: L. Reeve \& Co. vol.1. Pp. 209-213.

BFG - The Brazil Flora Group. 2015. Growing knowledge: an overview of seed plant diversity in Brazil. Rodriguésia 66(4):1085-1113.
BOCAGE-NETA, A.L. \& SALES, M.F. 2002. A família Bombacaceae Kunth no Estado de Pernambuco, Brasil. Acta Bot. Bras. 169:123-139.

CARVALHO-SOBRINHO, J.G. \& QUEIROZ, L.P. 2008. Ceiba rubriflora (Malvaceae: Bombacoideae), a new species from Bahia, Brazil. Kew Bull. 63:649-653.

CARVALHO-SOBRINHO, J.G. \& QUEIROZ, L. P. 2010. Three new species of Pseudobombax (Malvaceae, Bombacoideae) from Brazil. Novon 20:13-20.

CARVALHO-SOBRINHO, J.G. 2013. A new species of Eriotheca (Malvaceae: Bombacoideae) from Espírito Santo, Eastern Brazil. Phytotaxa 108:49-53.

DE CANDOLLE, A.P. 1824. Bombaceae. In Prodromus systematis naturalis reagni vegetabilis. París: victoris Masson et Filili, vol.5. Pp. 475-480.

DUARTE, M.C. 2010. Análise filogenética de Eriotheca Schott \& Endl. e gêneros afins (Bombacoideae, Malvaceae) e estudo taxonômico de Eriotheca no Brasil. Tese de Doutorado, Instituto de Botânica da Secretaria de Estado do Meio Ambiente, São Paulo.

DUARTE, M.C., ESTEVES, G.L., SALATINO, M.L.F., WALSH, K.C. \& BAUM, D.A. 2011. Phylogenetic analyses of Eriotheca and related genera (Bombacoideae, Malvaceae). Systematic Botany. 36:690-701.

DUARTE, M.C. 2015. Ceiba. In Lista de Espécies da Flora do Brasil. Jardim Botânico do Rio de Janeiro. http://floradobrasil.jbrj.gov.br/jabot/ floradobrasil/FB9034 (last access in 26/05/2019).

ESTEVES, G.L. 2005. Flora da Reserva Ducke, Amazonas, Brasil: Bombacaceae. Rodriguésia 56:115-124.

FLORA DO BRASIL 2020 (in preparation). Jardim Botânico do Rio de Janeiro. http://floradobrasil.jbrj.gov.br (last access on 26/05/2019).

GIBBS, P. \& SEMIR, J. 2003. A Taxonomic revision of the genus Ceiba Mill. (Bombacaceae). Anales del Jardín Botánico de Madrid. Consejo Superior de Investigaciones Científicas.

HICKEY, M. \& KING, C. 2000.The Cambridge Illustrated Glossary of Botanical Terms.

HICKEY, L.J. 1973. Classification of the Architecture of Dicotyledonous Leaves. Am. J. Bot. 60:17-33.

IBGE - PARAÍBA. 2018. Fundação Instituto Brasileiro de Geografia e Estatística. http://www.ibge.gov.br/estadosat/perfil.php? sigla $=$ pb (last access on 26/05/2019).

JUDD, W.S. \& MANCHESTER, S.R. 1997. Circumscription of Malvaceae (Malvales) as determined by a preliminary cladistics' analysis of morphological, anatomical, palynological, and chemical characters. Brittonia 49:384-405.

JUDD, W.S., CAMPBELL, C.S., KELLOGG, E.A. \& STEVENS, P.F. 1999. Plant systematics. A Phylogenetic approach. Sunderland: Sinauer Associates.

JUDD, W.S., CAMPBELL, C.S., KELLOG, E.A., STEVENS, P. \& DONOGHUE, M.J. 2009. Sistemática Vegetal - Um enfoque filogenético. $3^{\mathrm{a}}$ ed. Porto Alegre: Artmed.

LORENZI, H. 2002a. Árvores brasileiras. Manual de identificação e cultivo de plantas arbóreas nativas do

Brasil. $1^{\text {a }}$ ed. Nova Odessa: Instituto Plantarum. p. 352.

LORENZI, H. 2002b. Árvores brasileiras. Manual de identificação e cultivo de plantas arbóreas nativas do

Brasil. $2^{\mathrm{a}}$ ed. Nova Odessa: Instituto Plantarum. p. 352.

PARAÍBA. 2018. Secretaria de Estado da Ciência e Tecnologia e do Meio Ambiente. Agência Executiva de Gestão de Águas do Estado da Paraíba, AESA. PERH-PB: Plano Estadual de Recursos Hídricos: Resumo Executivo e Atlas, Brasília.

PAYNE, W.W. 1978. A Glossary of plant hair terminology. Brittonia 30:239-255.

PEIXOTO, A.L. \& MAIA, L.C. (Orgs.). 2013. Manual de Procedimentos para Herbários. INCT-Herbário Virtual para a Flora e os Fungos. Editora Universitária, UFPE, Recife.

PORTAL BRASIL. 2018. Estados Brasileiros - Paraíba. http://www.portalbrasil. net/estados_rn.htm (last access on 26/05/2019).

REYES, S.A. 1998. Bombacaceae. In Flora de Veracruz. Instituto de Ecología, A. C. Xalapa, Veracruz, México. p. 3-40. 
Figueiredo, S. S. et al.

RIZZINI, C.T. 1977. Sistematização terminológica da folha. Rodriguésia 42:103-125.

ROBYNS, A. 1963. Essai de Monographie du genre Bombax L. s.l. (Bombacaceae). Bulletin de Jardin Botanique de l'état à Bruxelles. 33:1-311.

SCHUMANN, K. 1886. Bombaceae. In K.F.P. Von Martius, A.G. Eichler \& I. Urban (eds.). Flora Brasiliensis 12:201-250.

THIERS, B. [continuously updated]. Index Herbariorum: A global directory of public herbaria and associated staff. New York Botanical Garden's Virtual Herbarium. http://sweetgum.nybg.org/ih/ (last access on 26/05/2019).
TROPICOS.ORG. 2018. Missouri Botanical Garden. http://www.tropicos.org/ Name/3900777 (last access on 26/05/2019).
Received: 20/07/2019

Revised: $13 / 03 / 2020$

Accepted: 18/03/2020

Published online: 18/05/2020 